\title{
DISTRIBUTION AND CHARACTERISTICS OF SUSPENDED SEDIMENT ON THE AMAZON SHELF
}

\author{
By Gail C. Kineke, Richard W. Sternberg, \\ David A. Cacchione, Kate Kranck \\ and David E. Drake
}

$\mathrm{T}_{\mathrm{H}}$ HE MAJOR goals of the AmasSeds sediment transport group are to determine the dominant physical processes causing sediment transport on the Amazon Shelf and to understand the particle response to these processes. The study was motivated by previous findings concerning such issues as: a) spatially variable sediment accumulation (from 0 to $10 \mathrm{~cm} \mathrm{y}^{-1}$; Kuehl et al., 1986); b) extreme sediment reworking depths/surface mixed layer thicknesses of up to $150 \mathrm{~cm}$ at water depths of $15 \mathrm{~m}$ (Kuehl et al., 1986); c) sediment dispersal (only $60-70 \%$ of the Amazon sediment discharge is accounted for; Nittrouer et al., 1986); and d) the origin of fine-scale stratigraphy. Although dynamic physical processes control the response of the sediments, the link between them can be complicated. Therefore a comprehensive study to document physical processes and simultaneous sediment response was initiated in this complex environment. Some preliminary findings are presented in this paper.

The field program was designed to measure the fluid, flow, and suspended-sediment characteristics throughout the water column and on varying time scales (e.g. semidiurnal, fortnightly, seasonal). Measurements fall into three major categories: suspended-sediment distribution throughout the water column; boundary-layer processes; and particle characteristics. Oceanographic cruises were scheduled during each season and period of river discharge (see Fig. 3 of Nittrouer $e t$ al. this issue) and three of the four cruises have been completed. Cruise IV is scheduled for OctoberNovember, 1991, during minimum river discharge. The cruises consist of legs designated for large-scale (spatial) surveys and anchor-station (temporal) surveys. The large-scale surveys contain up to 50 water-column profiles spaced along

G.C. Kineke, R.W. Sternberg, School of Oceanography, University of Washington, Seattle, WA 98195 USA. D.A. Cacchione, D.E. Drake, U.S. Geological Survey, Menlo Park, CA 94025 USA. K. Kranck. Bedford Institute of Oceanography, Dartmouth, Nova Scotia B2Y 4A2, Canada seven shelf-normal transects positioned between the river mouth and the French Guiana border (Fig. 1). The anchor stations consist of hourly profiles repeated over a 25 -h period at a specific location. Anchor stations have been occupied at inner-shelf locations across the topset beds of the River-Mouth and Open-Shelf Transects (see Fig. 1 of Nittrouer et al., this issue).

\section{Suspended-Sediment Distribution}

Measurements of suspended sediment throughout the water column were made using a small instrumented tripod (Sternberg et al., 1991) during the large-scale surveys and at all anchor stations. The tripod is used both as a profiler and to collect short time-series measurements while resting on the bottom. It continuously measures depth, suspended-sediment concentration (using an Optical Backscatter Sensor, OBS), current speed and direction, conductivity, and temperature, and obtains water and suspended-sediment samples at three preselected depths during each deployment.

Results of the large-scale surveys show that during a time of low sediment discharge (August 1989) the shelf could be characterized by three regions: a coastal zone ( $<12 \mathrm{~m}$ water depth) which was well-mixed in temperature, salinity, and suspended-sediment concentration $\left(1-3 \mathrm{~g}^{-1}\right)$; a midshelf region (15-30 m depth) with a stratified water column and suspended-sediment concentrations increasing toward the bottom $\left(\sim 0.8 \mathrm{~g} \mathrm{l}^{-1}\right)$; and an outer-shelf region ( $>40 \mathrm{~m}$ depth) characterized by near-bottom suspended sediment concentrations of approximately $0.1 \mathrm{~g} \mathrm{l}^{-1}$. The highest nearbed concentrations were observed close to the river mouth $\left(\sim 5 \mathrm{~g} \mathrm{l}^{-1}\right.$ at $\mathrm{z}=1 \mathrm{~m}, \mathrm{z}$ is height off the bed).

During times of high sediment discharge (February and May 1990) dramatic differences in the concentration and distribution of suspended sediment were observed. Fluid muds (here using a general definition for fluid mud of suspendedsediment concentration $>10 \mathrm{~g} \mathrm{l}^{-1}$; Ingliss and Allen, 1957; Krone, 1962; Wells, 1983; Faas,
During times of high

sediment discharge...

dramatic differences in

the concentration and

distribution of

suspended sediment

were observed. 


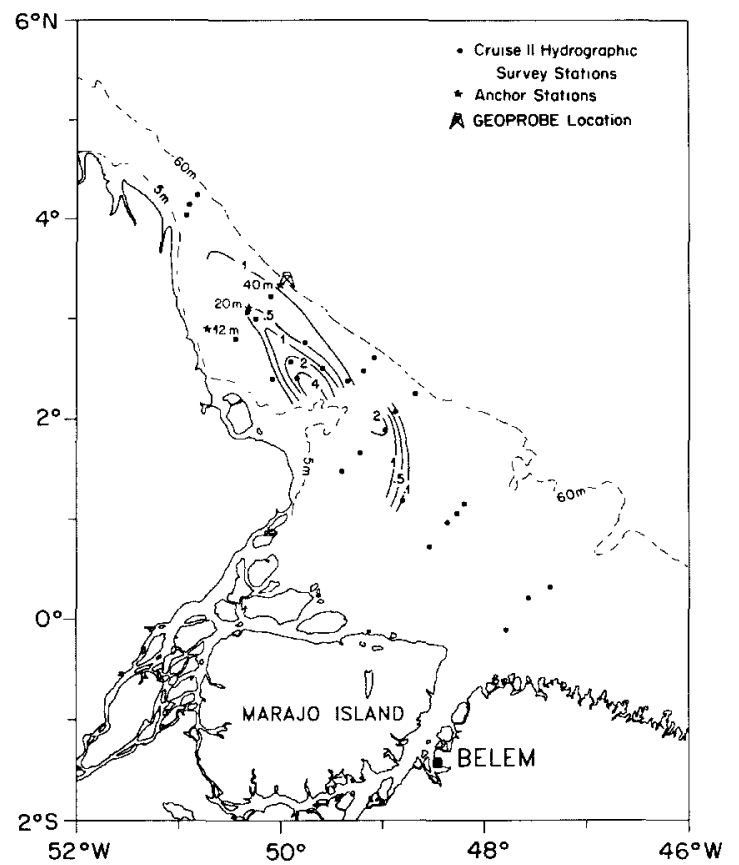

Fig. 1: Distribution and thickness of fluid mud (concentration $>10 \mathrm{gl}^{-1}$ ) during a period of high sediment discharge, February 1990. Solid contours are thickness in meters above the bed; dashed contours are water depth in meters. Also shown are the locations of the water-column profiles, GEOPROBE tripod, and Open-Shelf Transect anchor stations.

1986) were present over much of the shelf, and reached thicknesses (height above bottom) of up to $5 \mathrm{~m}$. During the February cruise, the fluid muds were localized to the mid-shelf region and were absent in the coastal zone and outer-shelf region (Fig. 1). Concentrations within the fluid-mud layer varied from 10 to $>200 \mathrm{~g} \mathrm{l}^{-1}$. In May, the fluid muds covered a broader region, including the coastal area, but were ephemeral and more variable in thickness. Along the River-Mouth Transect the presence of fluid muds was related to the spring/neap variations of water-column structure. During May, when the water column was wellmixed (during spring tide) fluid muds were absent, however, when the water column was stratified (neap tide) fluid muds were present.

Three anchor stations along the Open-Shelf Transect (Fig. 1) showed distinctly different suspended-sediment regimes. During low discharge, an anchor station at $20 \mathrm{~m}$ depth had maximum bottom concentrations of $0.8 \mathrm{~g} \mathrm{l}^{-1}(\mathrm{z}=20 \mathrm{~cm})$, and showed systematic changes marked by periods of resuspension, diffusion, and settling of sediment over a tidal cycle. These periods were characterized by an initial increase in bottom concentrations with increasing bottom velocity (resuspension), followed by decreasing bottom concentrations while velocities continue to increase and transfer sediment higher into the water column (diffusion), followed by decreasing sediment con- centrations at all levels in the water column as velocities decrease (settling) (Fig. 2). This is interpreted to be a cycle of transport limited by the amount of sediment that is readily able to be suspended - that is, the currents are capable of carrying more sediment than is available for resuspension and transport, but increasing shear strengths or cohesive effects just below the sediment surface inhibit further resuspension. The net flux over a tidal cycle was on the order of $2 \mathrm{~g} \mathrm{~cm}^{-1}$ $\mathrm{s}^{-1}$ toward the northwest and the vertically averaged suspended load (averaged over a tidal day) was $0.13 \mathrm{~g} \mathrm{~cm}^{-2}$.

In contrast, during high discharge (May) at the same site, fluid muds were present and transport over the tidal cycle was considerably different (Fig. $3)$. The thickness of the fluid-mud layer $(0.75$ to
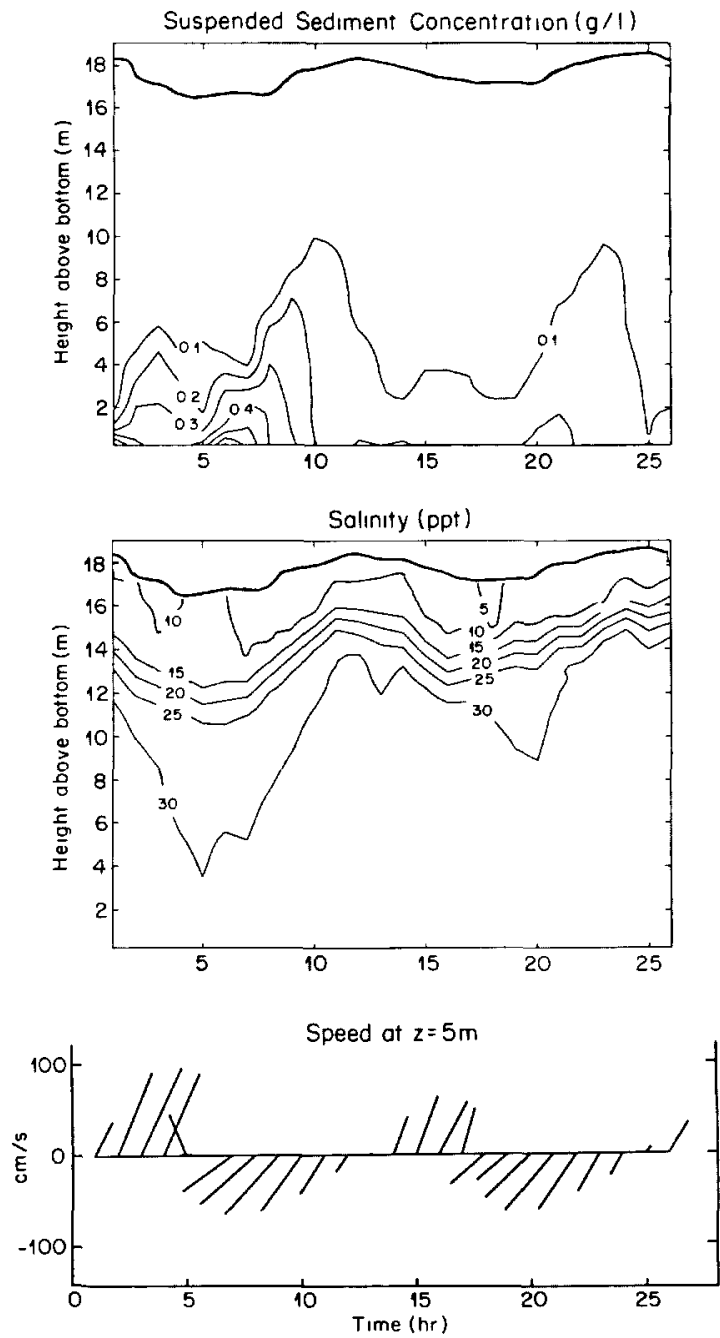

Fig. 2: Anchor station at $\sim 20 \mathrm{~m}$ depth, on the Open-Shelf Transect during low sediment discharge, August 1989. Profiles were made hourly for 25 hours. The upper panel shows the distribution of suspended-sediment concentration ( $g$ $\left.l^{-1}\right)$. The middle panel shows the distribution of salinity (ppt) and the lower panel shows current speed $\left(\mathrm{cm} \mathrm{s}^{-1}\right)$ at $5 \mathrm{~m}$ above the bed (positive vertical is north). See Figure 1 for station location. 

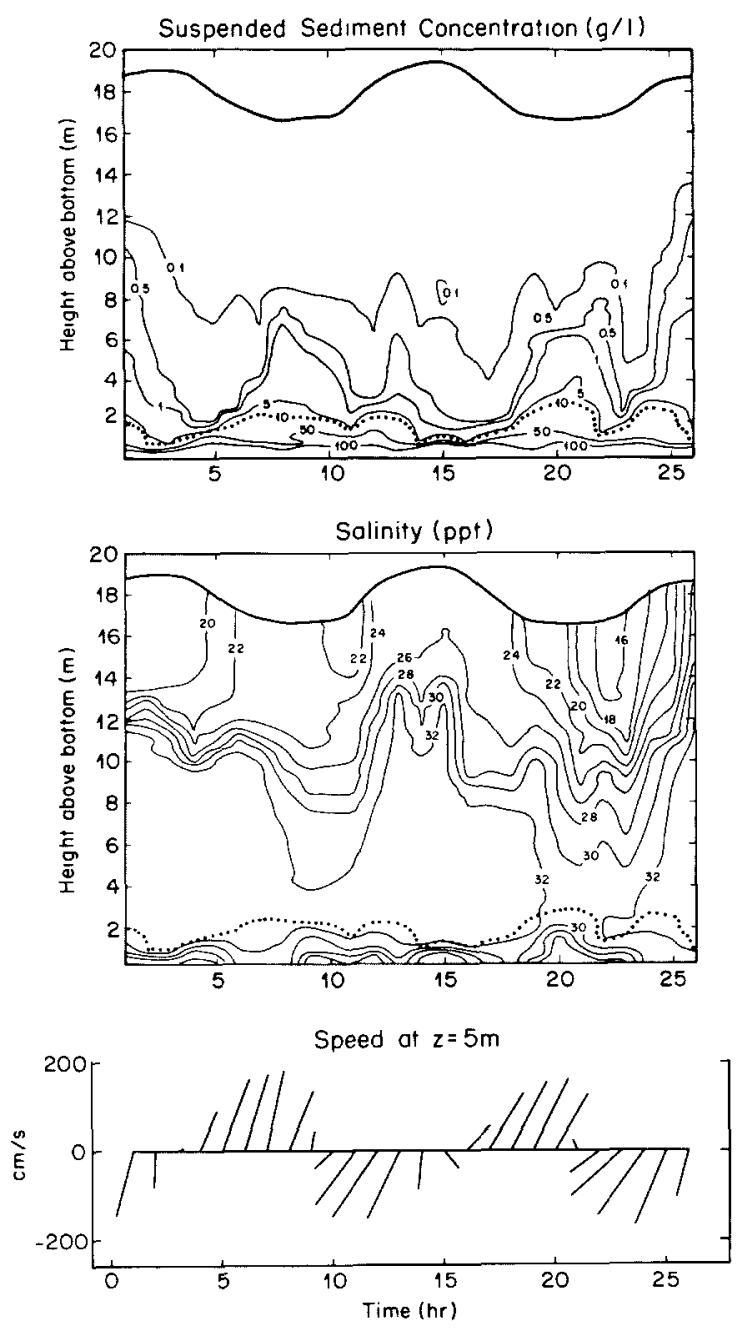

Fig. 3: Anchor station at $\sim 20 \mathrm{~m}$ depth on the Open-Shelf Transect during high sediment discharge. May 1990. Profiles were made hourly for 25 hours. The upper panel shows the distribution of suspended-sediment concentration $\left(g l^{-1}\right)$ with ... defining the top of the fluid-mud layer $110 \mathrm{~g}$ $\left.l^{-1}\right)$. The middle panel show's salinity distribution with the height of the fluid-mud layer ('.).) superimposed. The lower panel shows current speed at $5 \mathrm{~m}$ above the bed (positive vertical is north). See Figure 1 for station location.

$2.75 \mathrm{~m}$ ) varied with the speed of tidal currents, net flux was 40 times greater than during the time of low discharge, and mean suspended load was two orders of magnitude greater. Strong gradients in concentration within the fluid-mud layer were accompanied by strong shears in velocity. At the base of the fluid-mud layer was a layer of higher suspended sediment concentration $(50$ to $>100 \mathrm{~g}$ $\left.1^{-1}\right)$ that corresponds to anomalous decreases in salinity. The change in salinity does not appear to be related to conductivity sensor response at the high suspended-sediment concentrations. Rather, the high-concentration layer $\left(>50 \mathrm{~g} \mathrm{l}^{-1}\right)$ was being transported, but apparently was not mixing with the overlying water. The fluid muds can modify the transporting flow by damping tur- bulent mixing through strong stratification (Wolanski et al., 1988). Above the fluid-mud layer, sediment was resuspended into the lower water column (below the thermocline), lagging maximum velocities by $1-2$ hours. Transport at this time was not limited by the amount of easily suspendable sediment and was driven by tidal processes with important additional effects related to the behavior of the extremely high concentration suspensions (Nichols, 1984).

During the same cruise (May), the suspendedsediment regimes shoreward and seaward of the 20-m site were very different. Suspended-sediment transport at an anchor station in $40 \mathrm{~m}$ (Fig. 1) could be characterized as tide-dominated transport. Overlying a thin $(0.25-1.25 \mathrm{~m})$ layer of extremely high concentration fluid mud (hundreds of $\mathrm{g}^{-1}$ ) were relatively low concentrations of suspended sediment $\left(<1 \mathrm{~g} \mathrm{l}^{-1}\right)$ with logarithmic nearbed concentration profiles that varied with tidal currents. An anchor station at $12 \mathrm{~m}$ depth was somewhat transitional between a well-mixed water column in salinity, temperature, and suspended sediment, and a stratified water column with strong concentration gradients and fluid muds. Surprisingly, fluid muds were detected during flood tide and seem to be associated with the shoreward intrusion of high-salinity bottom water. The maximum height of the fluid-mud layer preceded the maximum bottom salinity, and, for a given velocity, total suspended loads could differ by an order of magnitude depending on the structure of the water column. Transport at this site was strongly influenced by frontal processes (i.e. processes associated with strong salinity gradients in the bottom water on the shelf).

\section{Boundary-Layer Processes}

The study of boundary-layer dynamics was carried out using an instrumented bottom tripod, GEOPROBE (Fig. 4; Cacchione and Drake, 1979). The tripod contains a variety of instruments to measure physical and sedimentological parameters which are important to understanding sediment processes at and near the seabed. Primary measurements include: horizontal velocity at four levels, bottom pressure, temperature, light transmissivity at two levels, optical backscattering at nine levels, and pumped water/suspended sediment samples at two levels. An acoustic altimeter pointed downward also provides valuable information on changes in the elevation of the seabed relative to the tripod. The GEOPROBE was deployed on February 11, 1990 (high sediment discharge) in $63 \mathrm{~m}$ water depth on the foreset beds along the Open-Shelf Transect (Fig. 1).

The GEOPROBE experienced an interesting and complicated deployment history as revealed in the acoustic altimeter data and by the successive burial of the various sensors nearest the seafloor. Upon deployment the tripod immediately settled about $50 \mathrm{~cm}$ into the soft bottom sediment, caus-
The GEOPROBE

experienced an

interesting and

complicated

deployment history . . . 


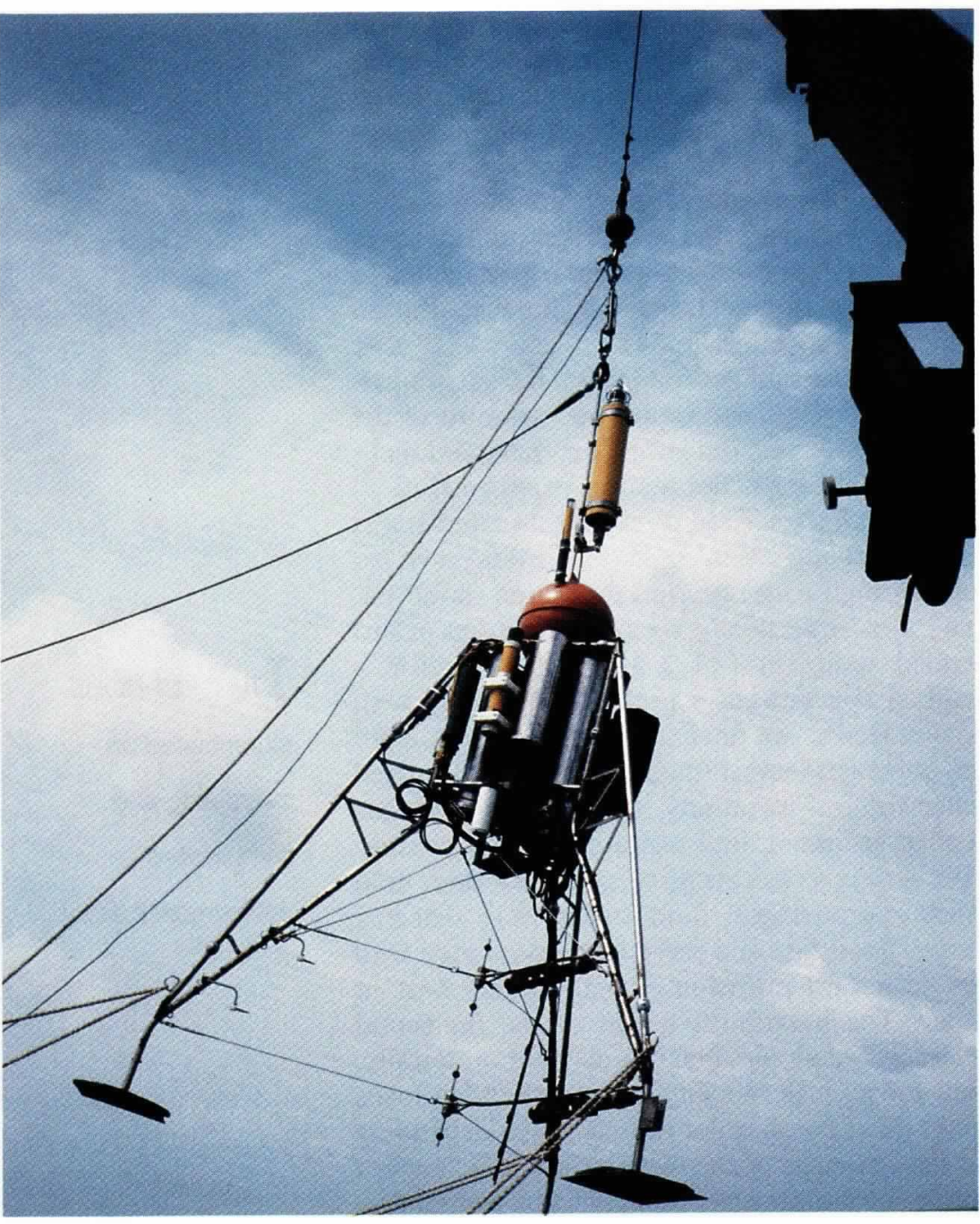

Fig. 4: The GEOPROBE tripod being deployed on 11 February 1990.

ing burial of the lowest current sensor and the two lowest optical backscattering sensors (OBS). On day 14 after deployment (February 25) the bottom suddenly elevated by about $40 \mathrm{~cm}$ over a period of about 12 hours. During this period two more current sensors and two additional OBS were buried. This significant short-term rise in the bottom was likely caused by a mud flow that moved down the delta foresets into the vicinity of the tripod. Finally, the altimeter data indicate that over the following 16 days, from February 27 to March 15, the seafloor gradually dropped about $12 \mathrm{~cm}$, probably due to a combination of dewatering of the rapidly deposited material and erosion by the strong tidal currents during spring tides.

Prior geological and geophysical work on the Amazon shelf had produced no direct evidence of slumping or other sediment failures. However, in addition to the event documented by GEOPROBE, $x$-radiographs of a box core taken at the GEOPROBE site approximately 10 days after deployment (by the Sedimentology and Stratigraphy Group of AmasSeds) show two distinct zones of soft-sediment deformation that might have been the result of previous mud flows or slumping.
Similar gravitationally induced sediment movements have been reported as common processes on other large submarine deltas (Prior and Coleman, 1980). The cause and triggering mechanism for this particular event on the Amazon shelf is unknown, but possible links to gas in the seafloor sediments and pore-water pumping by the large tidal range (over $3 \mathrm{~m}$ ) are under consideration.

Time-series data of water depth, near-bottom currents $(z=80 \mathrm{~cm})$, and suspended-sediment concentration $(z=176 \mathrm{~cm}$ and $14 \mathrm{~cm})$ are shown in Figure 5. These data demonstrate the large tidal motions near the seafloor as measured by the GEOPROBE sensors. The pressure signal has a distinct fortnightly cycle dominated by semidiurnal components, with maximum tidal range of $3.2 \mathrm{~m}$ on February 26 (day 15 on Fig. 5). The current speeds from the 3 current meters that operated over the early part of the record, prior to the sedimentation event (February 25-26), are coherent and were used to compute shear velocities $\left(u_{*}\right)$ and roughness lengths $\left(z_{0}\right)$ over the first 14 days. The values of $u_{100}$ (velocity at $z=100$ $\mathrm{cm}$ ) show distinct spring/neap variation, with maximum values of $55 \mathrm{~cm} \mathrm{~s}^{-1}$ during peak spring tide to approximately $20 \mathrm{~cm} \mathrm{~s}^{-1}$ during neap tide. Maximum bottom oscillatory velocities from waves were between $10 \mathrm{~cm} \mathrm{~s}^{-1}$ and $16 \mathrm{~cm} \mathrm{~s}^{-1}$ throughout the record. Wave periods determined from the burst pressure data were between $9 \mathrm{~s}$ and $15 \mathrm{~s}$. The sediment concentrations at about 1.8 $\mathrm{m}$ above the seafloor had peaks of about $0.4 \mathrm{~g} \mathrm{l}^{-1}$ over the first 14 days, with strong semi-diurnal fluctuations throughout the record. The mean current measured at the uppermost current meter was toward the northwest at $5 \mathrm{~cm} \mathrm{~s}^{-1}$ and would cause transport along the regional bathymetric contours of significant amounts of near-bottom suspended material.

\section{Particle Characteristics}

Investigation of particle size of both aggregates and constituent grains is being carried out to gain insights into the relationships between particle characteristics, salinity distribution, flow conditions, and sediment accumulation (e.g. accumulation rates and fine-scale stratigraphy). Suspended aggregates are photographed in situ with a Benthos plankton camera (Sternberg et al., 1988) and disaggregated grain characteristics of bottom and suspended sediment are analyzed using a Coulter Counter (Kranck and Milligan, 1979; Milligan and Kranck, 1991). Sampling procedures involve use of Niskin bottles and pumps to collect suspended-sediment samples and a Benthos plankton camera for in situ photographs from multiple depths and locations during the large-scale surveys and anchor stations.

Analyses of sediments collected during low discharge have been separated into a floc fraction and a grain fraction. Constituent material comprising the floc fraction consists of poorly sorted 

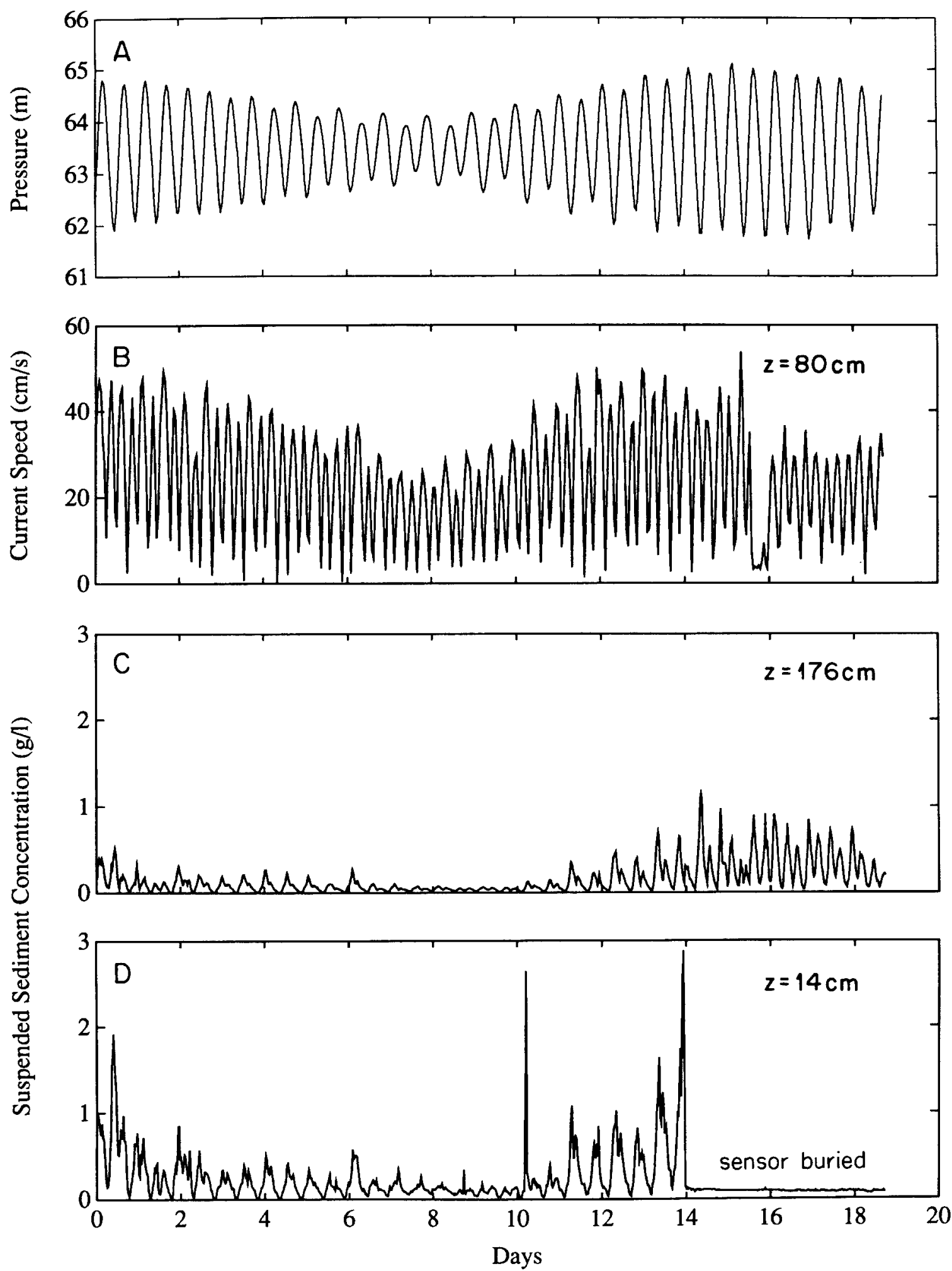

Fig. 5: Example of data collected from the GEOPROBE tripod at $63 \mathrm{~m}$ depth on the Open-Shelf Transect (see Fig. I for station location). A) pressure $(m) ; B)$ upper current-meter speed record $\left(\mathrm{cm} \mathrm{s}^{-1}\right)$, at $z$ $=80 \mathrm{~cm}$ prior to sedimentation event at 14 days; and $C$ and $D)$ suspended-sediment concentration at $z=176$ and $14 \mathrm{~cm}$ prior to sedimentation event. 0 days $=1430$ local time on 11 February 1990.

silts and clays with equal volumes of material in all size classes. The grain fraction consists of sand sizes generally less than $100 \mu$. Image analyses of photographs of aggregates in the water column indicate a well sorted size distribution with modal aggregate size ranging from $200-700 \mu$.
From these analyses a pattern is emerging regarding sediment aggregation on the Amazon shelf. First, the percent of bottom sediment deposited from aggregates increases away from the river mouth and toward the northwest (Fig. 6). This observation, along with the lack of variation
... the percent of bottom sediment deposited from aggregates increases away from the river mouth and toward the northwest. 


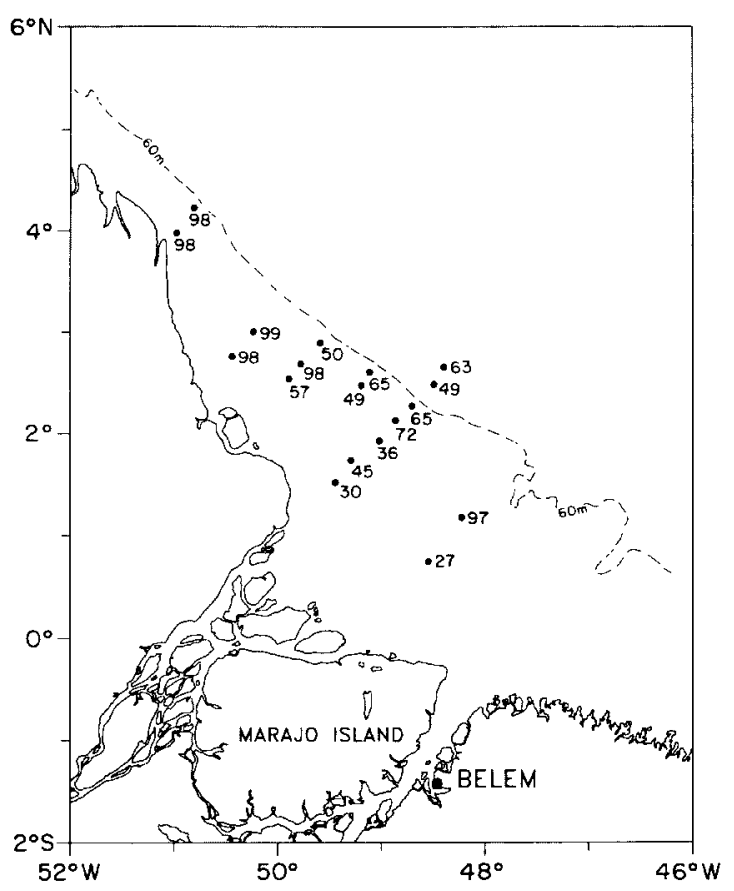

Fig. 6: Percent of bottom sediment deposited in a flocculated form. The percentage of aggregates generally increases northwestward away from the river mouth, suggesting an increase in this same direction for particle average settling velocity.

in the maximum size of the single grain-settled fraction suggests that particle aggregation is more strongly related to residence time along the dispersal path than the intensity of flow conditions. Secondly, based on inferences from these observations, an increase in average settling velocity away from the river mouth associated with aggregate formation is suggested.

\section{driving sediment}

transport include tides,

waves, and processes

associated with strong

salinity gradients on

the shelf. findings of deep surface mixed layers, high sediment accumulation rates, and estimates of sediment dispersal. Future analyses will continue to focus on these areas of investigation in order to better understand the link between controlling physical processes and the fate of Amazon River sediment.

\section{Acknowledgements}

The authors acknowledge H. Vital, C. Sherwood, T.G. Milligan, G. Tate, J. Thede, and R. Viall for their contribution in the field and the lab. This research was sponsored by the U.S. National Science Foundation Grant OCE-8813399. School of Oceanography, University of Washington, Contribution 1887.

References

Cacchione, D.A. and D.E. Drake, 1979: A new instrument system to investigate sediment dynamics on continental shelves. Mar. Geol., 30, 299-312.

Faas, R.W., 1986: Mass-physical and geotechnical properties of surficial sediments and dense nearbed sediment suspensions on the Amazon continental shelf. Cont. Shelf Res., 6, 189-208.

Ingliss, C.C. and F.H. Allen, 1957: The regimen of the Thames as affected by currents, salinities and river flow. Proc. Inst. Civil Eng., 7, 827-878.

Kranck, K. and T. Milligan, 1979: The use of the Coulter Counter in studies of particle-size distributions in aquatic environments. Bedford Institute Rept. 79-7.

Krone, R.B., 1962: Flume studies of the transport of sediment in estuarial shoaling processes. Final Rep. Hydraulic Engr. Lab Sanitary Eng. Res. Lab., Univ. California, Berkeley, CA, 110 pp.

Kuehl, S.A., D.J. DeMaster and C.A. Nittrouer, 1986: Nature of sediment accumulation on the Amazon continental shelf. Cont. Shelf Res., 6, 209-225.

Milligan, T. and K. Kranck, 1991: Electro-resistance particle size analyzers. In: Theory, Methods and Applications of Particle Size Analysis, J.P. Syvitski, ed.. Cambridge University Press, New York.

Nichols, M.M., 1984: Fluid mud accumulation processes in an estuary. Geo. Mar. Lett. 4, 171-176.

Nittrouer, C.A., T.B. Curtin and D.J. DeMaster, 1986: Concentration and flux of suspended sediment on the Amazon continental shelf. Cont. Shelf. Res., 6. 151174.

, D.J. DeMaster, A.G. Figueiredo and J.M. Rine, 1991: AmasSeds: an interdisciplinary investigation of a complex coastal environment. Oceanography, 4, 3-7.

Prior, D.B. and J.M. Coleman, 1980: Sonograph mosaics of submarine slope instabilities. Mississippi river delta. Mar. Geol., 36, 227-239.

Sternberg, R.W., K. Kranck, D.A. Cacchione and D.E. Drake, 1988: Suspended sediment transport under estuarine tidal channel conditions. Sed. Geol., 547, 257-272.

, G.C. Kineke and R. Johnson, 1991: An instrument system for profiling suspended sediment, fluid and flow conditions in shallow marine environments. Cont. Shelf Res., II, 109-122.

Wells, J.T., 1983: Dynamics of coastal fluid muds in low-, moderate-, and high-tide-range environments. Can. Jour. Fish. Aquat. Sci., 40 (Suppl. 1), 130-142.

Wolanski, E., J. Chappell, P. Ridd and R. Vertessy, 1988: Fluidization of mud in estuaries. Jour. Geophys. Res.. 93, 2351-2361. 